\title{
Confessions of a Legend Hunter in the U.S.A.
}

Janet Langlois

\section{(2) OpenEdition}

Journals

Édition électronique

URL : https://journals.openedition.org/clo/198

DOI : $10.4000 /$ clo. 198

ISSN : 2266-1816

Éditeur

INALCO

\section{Édition imprimée}

Date de publication : 1 janvier 2008

Pagination : 185-200

ISBN : 978-2-85831-181-1

ISSN : 0396-891X

Référence électronique

Janet Langlois, " CONFESSIONS OF A LEgend HUNTER IN THE U.S.A. », Cahiers de littérature orale [En ligne], 63-64 | 2008, mis en ligne le 31 décembre 2011, consulté le 07 juillet 2021. URL : http:// journals.openedition.org/clo/198; DOl : https://doi.org/10.4000/clo.198

Ce document a été généré automatiquement le 7 juillet 2021.

\section{(c) (7) \&}

Cahiers de littérature orale est mis à disposition selon les termes de la Licence Creative Commons Attribution - Pas d'Utilisation Commerciale 4.0 International. 


\title{
Confessions of a Legend Hunter in the U.S.A.
}

\author{
Janet Langlois
}

\section{LEgEND AND CLASSIC ETHNOgRAPHY IN MINIATURE}

1 It strikes me that I have been doing field research on American legends for 30 years or more, just about the amount of time Elliott Oring recently noted that European and American legend scholars have been arguing about this narrative genre, how to classify and interpret its texts, performance contexts and its relationships to other forms of expressive culture (Oring, $2008: 128$ ). My premise in this review is, then, that some of my ethnographic forays into legend worlds (and related worlds of rumor, personal experience narrative and ritual) mirror in some ways the general legend-collecting strategies, interpretive frames and debates in American folkloristics over three decades, and so may be useful in the broader discussions of fieldwork and oral literature.

2 My first adventures as a legend hunter began in 1972 when I was a graduate student at the Folklore Institute, Indiana University, taking a legend seminar with Linda Dégh who had brought European concepts of the genre to the U.S. when she had emigrated from Hungary in 1964 (Dégh, 1995: 9-29; Dégh, 2001: 9-22; Tucker and Langlois, 2005: 129-140). Upon her urging, I drove up with several other students from the Bloomington, Indiana campus to Indianapolis to attend a Psychic Fair there one fall day in October. Although I did not interview any psychic healers then, I did strike up a conversation with a young African-American woman, Gia, then 12 years old, who was also attending. She told me that she and a number of her friends at her elementary school in Indianapolis regularly called a spirit back in a mirror in the girls' bathroom during recess and lunch breaks, and that the spirit they called back was that of a young woman they called Mary Whales who had been killed while hitchhiking on a major street near their school. 
3 Recognizing a version of "the Vanishing Hitchhiker" legend when I heard it, I arranged with Gia's school staff to work with students during a weekly two-hour period in which community members could come to the school and interact with students in an experimental program. I see now how many factors came together so that I could do this research. At the time, however, doing a broad survey of 80 students with questionnaires and focus groups, interviewing and audio-taping selected students (10 young women in particular with Gia their leader), spending several nights at schoolsponsored slumber parties as a participant-observer, and observing re-enactments of the "ritual" of calling Mary Whales who they expected would emerge from the mirror to scratch them (a.k.a. "Bloody Mary") were all that I could manage (Dégh, 2001: 243-46; Ellis, 2004: 142-73; Dundes, 1998; Hawes, 1968; Tucker, 2005, Campus Legends: 178-79; Tucker, 2005, “Ghosts in Mirrors": 186-203).

4 Although these multiple approaches to fieldwork are ones that I still see as ideal in any field-research based collection of folk narratives (short of field teams working together), I did not discuss my fieldwork experiences in the research paper that I wrote for the seminar nor in the 1978 article that grew from it in any depth (Langlois, 1978: 7). Perhaps I sensed or was told that field researchers, whether anthropologists, ethnologists or folklorists, usually did not discuss conditions in the field in print unless in introductions, footnotes or in separate memoirs, seen as marginal at that time. I rather guess I simply didn't think of it, although I did recognize that my presence as ethnographer did make the "Mary Whales thing" get bigger. (Clifford and Marcus, 1986: 1-26, 262-66; Emerson et al., 1995:1-38; Langlois, 1978: 7 idem).

5 I focused instead on examining the relationship between the legendary origin stories students told about Mary Whales and their own personal experience narratives of calling her. I built a case that, as the hitchhiker killed by a truck moved from a passive to an active, albeit, malevolent position when called in the mirror, so did these students move from a more passive position to a more active one in the very act of calling her. Clearly, I was deeply influenced by structural models for evaluating myth and ritual, dominant at that time, rich in the possibilities of validating narrative study on the abstract level of Langue.

6 Yet this early fieldwork experience, a "classic ethnography" in some ways, was embedded in Dégh's defining concept of the legend as a dialectical genre in which participants debated the veracity of the stories under discussion (Dégh, 2001; Dégh and Vazsonyi, 1973; Oring, 1986: 125-26; Oring, 2008: 143-45). It ultimately rested on the importance of extra-textual features in specific settings (paroles). Young women called Mary Whales in mirrors in various settings, and young men sometimes watched them running out of the bathroom screaming, and later teased them about it. In spite of myself, I had taken gendered contexts into consideration in both describing the narrative and ritualized situations and in interpreting their general meaning as I saw it. Young women transformed themselves ritually through actualizing narratives of another young woman, not so different from themselves, although spectral, in cultural settings that favored the active over the passive, a proto-feminist position that I would develop somewhat more fully in later research more performance oriented. 


\section{INTIMATE ETHNOgRAPHY: FEMINISM, FIELDWORK AND PSYCHOANALYSIS}

7 Alan Dundes' critique of that early article twenty years later in 1998 basically replaced the structural model underlying it with a psychoanalytical one, concluding that girls enacted the "Bloody Mary" narrative and ritual only as a way to deal with their fear of menarche (1998). Although I did not argue with him at the time, I had conducted an earlier field research project on another legend complex in which I had countered standard psychoanalytical readings with emerging feminist approaches that can be seen as my indirect response (Langlois, 1993). The project began as serendipitously as the first when a good friend Alice telephoned me in 1978 from Colorado to tell me about a disturbing story she had heard twice (once in 1968, then in 1978 shortly before she called me) about a mother who had lost her children through her own incompetence. Alice wondered what to make of it and asked for my input. I had just starting teaching folklore courses in the English Department at Wayne State University in Detroit, Michigan the year before so she must have seen me as an expert in twicetold tales.

8 In the first instance, Alice had been 22 in 1968, working at her first job after college at a bank in Colorado Springs, Colorado. On one of the coffee breaks she took with several older women bank employees who had taken her under their wings, one woman had told the others that she'd heard about a mother in the area who had lost her baby boy. When her three-year-old daughter had pointed to her baby brother's penis and asked what it was, the mother had responded, "Oh, that's something the doctor forgot to cut off at the hospital." When she left the room for a moment, the daughter cut off the baby's penis with a scissors, and he had bled to death before the mother could get him to the hospital. When I formally interviewed her in 1988, Alice recalled her response the first time,

I remember feeling shock and horror and thinking how terrible that must have been and what a tragedy it was. And just thinking how awful that mother must have felt... and I believed this story absolutely.

(as quoted in Langlois, 1993: 81).

In the second instance, Alice was a new mother with a baby boy herself in 1978, living and teaching in Albuquerque, New Mexico when she heard the same story again at a dinner party with other new parents. In this case, the hostess telling the story noted a double tragedy: the mother ran over the daughter while frantically trying to get the castrated baby boy to the hospital and so both children died. Alice recalled her response the second time:

[A]s soon as Theresa started telling the story - the bells went off - and I thought,

I HEARD this story before. I KNOW WHAT'S COMING. I KNOW HOW THIS STORY IS GOING TO END." And so I was not horrified. I was not shocked [...] But the other people around the table, especially the fathers [...] were very uncomfortable.

(as quoted in Langlois, 1993: 81-2)

10 Teaching young children herself at the time of our interview, Alice no longer sympathized with the legendary mother but with the legendary child victims. She noted how their lives ended because their mother was linguistically and behaviorally inept, and she could not accept the maternal negligence of which the stories warned. 
Our interview in 1988 was what I came to call privately an "intimate ethnography," loosely based on the 1993 feminist critique of the "objective" stance of many literary critics in The Intimate Critique: Autobiographical Literary Criticism (Freidman et al., 1993). Intimate field research began with considering a single in-depth qualitative interview with a woman I knew well as a valid data base for analysis. It was ethnography as a personal conversation that yielded fuller contextual data including Alice's responses to the two performances of the legends she reported hearing at different times in her life as indicated above. It allowed for exchange between interviewer and interviewee, what Elaine Lawless would name "reciprocal ethnography" in her own fieldwork with women interviewees in various settings (Lawless, 2000: 197-205; 1991: 35-60).

In retrospect, I see that I worked very hard, perhaps too hard, in the interview situation itself to bring Alice back to sympathy with the over-burdened mother in legend I saw crushed by the very institution of motherhood. I had reasons for that advocacy. Personally, I was a new mother myself, and, professionally, I was motivated by the exciting combination of feminism and folklore re-energizing folklore studies (Farrer, 1975; Hollis, et al.,1993; Jordan and Kalcik, 1985; Mills, 1993: 173-92; Radnor, 1993). In the chapter, "Mothers' Double Talk," published in Feminist Messages: Coding in Women's Folk Culture in 1993, I re-examined Alice's interview through various critical lenses including French and American feminist scholarship. In the process, I re-read Michael P. Carroll's psychoanalytical study of "The Castrated Boy" legend (Carroll, 1987: 216-25) and applied it to versions of "The Inept Mother," but suggested that the legend subtexts were not a resurgence of women's penis envy reactivated by the women's movements as he argued, but possibly a symbolic desire for women's "getting even" in which boys become more like girls in a positive sense (Langlois, 1993: 86-90).

\section{SHADOW ETHNOgRAPHY: RUMOR AND LEgEND AND THE RELUCTANT FIELD RESEARCHER}

Playing with conflicting psychoanalytic readings of the place of women in society above paradoxically pushed me into considering legend telling in contexts of social issues or problems, and into seeing this narrative genre as a sign of, if not a lightening rod for, cultural dissonance sprouting in the cracks of social systems. This approach to legend telling merged folklorists' formative concept of legend dialectics with sociologists' and socio-psychologists' concepts of rumor formation and transmission, often in terms of class, ethnic or racial conflict, and mirrored multidisciplinary work in Europe and America (Klintberg, 1986, 1984; Bennett, 2005; Bennett and Smith, 2007; CampionVincent, 2005; Campion-Vincent and Renard, 2002; Fine, 1992; Fine, Campion-Vincent and Heath, 2003; Fine and Turner, 2001; Kapferer, 1990; Knopf, 1975; Renard, 1999; Tucker, 2005 [book]; Turner, 1993). The relationships of (and the tension concerning) the terms "legend" and "rumor" themselves indicated this generative mix of approaches exemplified in Rumor Mills: The Social Impact of Rumor and Legend, based on a multidisciplinary conference in 2003 (Fine, Campion-Vincent, Heath), and in Contemporary Legend, the journal of the International Society for Contemporary Legend Research (ISCLR), among others. For the record, I see "rumor" as unverified statements that may develop into "legend" as narrative form, but that both terms, signaling communication patterns, have been interpreted in much the same way, and are sometimes used interchangeably in this literature. 
14 I'd like to discuss briefly three studies I conducted that were embedded within these shared paradigms. Paradoxically again, just as interest in narratives of cultural difference and social issues emerged in related disciplines, critiques of ethnographic methodology as a whole arose in post-colonial and cultural studies. I found myself as ethnographer caught in a double bind: I was both interested in listening to "rumormongers" and legend tellers in an array of social contexts, and concerned about invading their personal and cultural domains. My solution was what I called my "shadow ethnography" (Langlois, 2005: 233) in which I drew on the ethnographic work done by students and colleagues for my analyses, yet another sort of appropriation perhaps. In the first case (Langlois, 1991:153-72), I was teaching an introductory composition course in the English Department at Wayne State in 1988, infusing it with as much folk material as possible, selecting what $I$ liked to read (as one disgruntled student reviewer wrote later). I had asked students, most of whom were freshmen, to keep journals of "stories that they had heard on the street" including the specific social contexts in which they had heard them. Then each student was required to select one entry to use as a base for an argumentative paper. When reading their journals, I was surprised to come across reports (four reports in 25 journals) of a legend complex dubbed "Hold the Mayo" among researchers (Brunvand, 2001: 252; Koenig, 1985; Smith, 1990: 113-41). It was one of the first anti-gay, blame-the-victim narratives I had heard in which a young man who works in a Burger King fast food franchise, had learned that he had contracted AIDS. Not wanting to die alone, he ejaculated into Burger King's famous mayonnaise sauce, infecting customers.

These narratives, what Paul Smith has called "sex revenge" legends (1990), fused mercantile legends of food contamination ("foreign objects in food" motifs), usually correlated with critiques of dangerous or incompetent corporations (Brunvand, 2001: 252; Fine, 1992; Koenig, 1985; Turner, 1993, 137-64), with AIDS contamination as one type of illness narrative (Goldstein, 2004; Turner, 1993, passim). All the students reported hearing variations of "Hold the Mayo" in fast food restaurants or in cars eating fast food, and determined not to eat at Burger Kings again. I concluded, somewhat globally, that these young adults sensed the dark side of late capitalism, and their own involvement in it, in the world-wide transmission of AIDS and "industrial pollution and the new system of global financial markets [...] that are the by-product of advanced society [...]" (Sontag, 1988: 92).

The last two studies, published in the Journal of American Folklore over twenty years apart, examine racial and ethnic rumors and legends in Detroit, the city many see as the harbinger of a dystopic future, but one I still call home. The earlier study examined rumor and legend dialectics about the start of the 1943 Detroit race riots, drawn in part from interviews conducted in 1970 by folklorist Richard A. Reuss's graduate students in the Anthropology Department, now housed in the Wayne State University Folklore Collection at the Reuther Archives of Labor and Urban Affairs (Langlois, 1983b: 183-199). Literally etched in black and white, paired but conflicting stories outlined the racial tensions in the city: the rumor that black men had raped a white woman circulated in the largely Southern Appalachian section of the inner city on the west side of Woodward Avenue, the street that divided the city in half, while the rumor that white men had thrown a black woman and her baby off the Belle Isle Bridge into the Detroit River circulated in the largely Southern Black community to the east of Woodward Avenue. At this point, the rumors confirmed Terry Ann Knopf's findings 
that shared but opposed rumors of atrocities, especially towards children, figure prominently in riots as in wartime (Knopf, 1975: 155-56). Later, in the official reports of the riot, the rumor in the black community only was said to have caused the rioting, subsequent loss of life and property damage, an instance of the asymmetry of power relations.

While the earlier study focused on racial tensions locally in Detroit, the later study focused on rumor and legend dialectics in post-9/11 Detroit in a more global sense. Drawn from a Detroit journalist's research into the part e-mails played in transmitting and responding to rumors, it examined the rumor that Arab and/or Muslim employees of a Detroit-area Middle-Eastern restaurant had cheered when footage of both planes crashing into New York City's Twin Towers had aired on television during the lunch hour (Langlois, 2005: 219-36). This rumor, primarily circulating on listserves in the Jewish-American communities on the northwest side of Detroit, was much like those circulating in other U.S. cities (Fine and Khawaja, 2005: 189-205) and on the Internet (Mikkelson), and had a like effect of boycotting the restaurant in question. Yet I built a case that local dimensions of the rumor network needed to be kept in mind by researchers so that the analyses of local difference could be interwoven into the discussions of the global reach of the World Wide Web. Seeing the distinctiveness of the Jewish-Arab contexts in Detroit paradoxically demanded considering the connections to the Middle East in another set of global relationships. I concluded:

The continued boycott of the Sheik Restaurant can be seen as misplaced anger..., but even more, as a disturbing reminder of the intricate connections between here and there, a supplemental pattern of social conflict that resists premature healing, even as all the attempts to end it must continue.

(Langlois, 2005: 232)

Emerging studies of the complex, interrelated worlds of rumor and legend on the Internet, e-mail, blogs and other electronic communication are important aspects of documenting and evaluating digital culture (Brunvand, 2001: 211-13; Byrd, 2002; Ellis, 2002).

\section{CONCLUSION: SHARED ETHNOgRAPHY}

The Detroit rumor and legend studies, in both their local and global contexts, bring me to a discussion of oral narrative and community and a sense of shared ethnography with which I will conclude. Two fuller ethnographic studies frame my career as a legend hunter to date. The first, my 1977 doctoral dissertation at Indiana University turned book in 1985 (Belle Gunness, The Lady Bluebeard), focused on the multiple narrative representations of a woman serial murderer who put a small Indiana town "on the map" at the turn of last century (See also Langlois, 1978; 1985a: 109-24 [in 1983a: 617-34). Belle Gunness stories put legend dialectics on a community scale as La Porte, Indiana residents have debated whether she was a man or a woman, whether she killed 12,16, 42 or 200 Norwegian men who had answered her matrimonial ads, and whether she got away or not ever since her farmhouse burned down in 1908 and body parts were found there. In preparing for a recent Gunness 100th Anniversary Lecture Series in the town in 2008, I reviewed notebooks from my 1975-76 and 1981 fieldwork there, and was amazed to see that I'd interviewed 200 people who were considered 
experts on the Gunness case or who had been eyewitnesses or had family stories about her (I was young then!).

But I focus here on my collaboration with an earlier researcher, a historical crime writer, Lillian De La Torre, who had done research in La Porte in 1952 for her 1955 The Truth about Belle Gunness. By one of those strange coincidences, I found that she was living in my hometown of Colorado Springs, Colorado, and she opened her files for me because a Scottish researcher had done the same for her in an earlier writing project. Her fieldwork notes gave me comparative material that was very useful in tracing changing attitudes toward the mass murderess, and in tracing shifts from personal experience narratives to family stories to community legends. What I call "The Anchor Story" is case in point. Frank Coffeen, a handyman who worked for Belle Gunness, testified at the inquest held in 1908 that she had seemed "kind of startled and confused" when he'd come up to her barn to "borrow" an anchor rope he needed for fishing. By the time De La Torre interviewed him in 1952, he told her that Gunness had met him at the back of the house, yelled at him about the rope - "Go get it. And don't return." - so that he knew something was wrong. When I interviewed his son Bob Coffeen in 1976, his rendition of his Dad's story highlighted the conversation concluding with her, "Well, get the rope and get off my property." And his narrative coda summed up later understandings: What he was doing, of course, was walking across part of her private graveyard (Langlois, 1985: 73-4 [book]).

21 The second project is still on-going, and, in a certain sense, has just begun. Its working title is overly long, but nevertheless summarizes its focus: “'Other Worlds': An Ethnographic Study of Personal Accounts of the Return of the Dead and Other Mystical Experiences in Health-Related Contexts." It began when I mentioned to my brother that I had heard that seeing the recently-deceased loved one can be a part of the grieving process as we mourned together shortly after the memorial service for his wife five years ago (Hufford, 1995: 19). My brother's response that the hospice worker had told him that that was a possibility struck a chord with me. I wanted to know what some of these experiences were, how people talked about the numinous in these sorrowful moments and beyond, how hospice and hospital staff responded, and how the literature in a number of disciplines related to a folkloristic approach to revenants. The study I've been conducting since 2003 as the principal investigator has two parts: interviewing willing individuals who have experienced or witnessed the numinous in these settings, and administering questionnaires and interviewing staff and volunteers at a local hospice. Two researchers - an anthropology graduate student and a hospice volunteer who is also a social worker - have also conducted interviews and transcribed some of the audiotapes as key personnel on the project (Human Investigation Committee \#069403B3E).

As the project has progressed (and we are moving more slowly and more delicately now than when I was a graduate student in the 1970s as the interviews cover more private information, and I'm older!), I have been most grateful for those people willing to participate in the project, for administrators permitting the research, for those colleagues sending me their own ethnographic data on similar topics and for those studies that deal with the moments between life and death in a compassionate way. I'm just entering the world of palliative medicine and hospice care, and the cultural approaches to the mysteries, both sacred and secular, that lie there. I find that folklorists are among those involved in this research already (Barnard et al., 2000; 
Bennett, 1999; Brady, 1987; Dégh, 2001: 382-94, Gelfand et al., 2005; Hufford, 1995; Tangherlini, 1998; Zeitlin and Harlow, 2001). Perhaps team research, the ideal with which I began this confession about oral literature and ethnography, is already here in many cases.

As the papers I have given on this data have tended to focus on one interview setting at a time, intimate ethnography reworked, performance models may more strongly intersect with the structural methodologies I find still useful in folk narrative field research. As the project began with my own sorrow, and includes my own narratives of the numinous, I hope that more self-reflective moments as ethnographer await me, the power of narratives to inform and reveal the personal in group contexts (Langlois, 2006).

\section{BIBLIOGRAPHIE}

BARnARD, David, Towers, Anna, Boston, Patricia and LAmbrinidou, Yanna, 2000, Crossing Over: Narratives of Palliative Care. New York: Oxford University Press.

BENNETT, Gillian, 1999, Alas, Poor Ghost! Traditions of Belief in Story and Discourse. Logan: Utah State University Press.

BENNETT, Gillian, 2005, Bodies: Sex, Violence, Disease, and Death in Contemporary Legend. Jackson: University Press of Mississippi.

BENNETT, Gillian and SMITH, Paul (eds), 2007, Urban Legends: A Collection of International Tall Tales and Terrors. Westport, CT: Greenwood Press.

BRADY, Erika, 1987, The 'Beau Geste': Shaping Private Rituals of Grief. Folklife Annual. 24-33. Rpt. in Zeitlin and Harlow.

BRUNVAND, Jan Harold, 2001, Encyclopedia of Urban Legends. New York and London: W.W. Norton.

BYRD, Donald A., 2002, 'Holy Smoke!' Legend and Belief: Dialectics in the New Media. Paper presented at the American Folklore Society Annual Meetings, Rochester, New York, October $16-20,2002$.

CAMPION-Vincent, Véronique, 2005, Organ Theft Legends. Trans. Jacqueline Simpson. Jackson: University Press of Mississippi.

CAMPION-VINCENT, Véronique and RENARD, Jean-Bruno, 1992, Légendes urbaines : Rumeurs D'aujourd'hui. Paris, Payot.

CAMPION-VINCENT, Véronique and RENARD, Jean-Bruno, 2002, De Source Sûre : Nouvelles Rumeurs D'aujourd'hui. Paris, Payot.

CARROLL, Michael P., 1987, 'The Castrated Boy': Another Contribution to the Psychoaalytic Study of Urban Legends. Folklore 98.2: 216-225.

CLIFford, James and MARcus, George E. (eds), 1986, Writing Culture: The Poetics and Politics of Ethnography. Berkeley: University of California Press. 
DÉGH, Linda, 1995, Narratives in Society: A Performance-Centered Study of Narration. FFC Communications no. 255. Helsinki: Suomalainen Academia Scientiarum Fennica.

DÉGH, Linda, 2001, Legend and Belief: Dialectics of a Folklore Genre. Bloomington, Indiana University Press.

DÉGH, Linda and VÁZSONYI, Andrew, 1973, Dialectics of the Legend. Folklore Preprint Series. 6. Bloomington : Indiana University Folklore Institute.

DE LA TORRE, Lillian, 1955, The Truth About Belle Gunness. NY: Gold Medal.

DunDES, Alan, 1998, Bloody Mary in the Mirror: a Ritual Reflection of Pre-pubescent Anxiety. Western Folklore 57:2/3: 119-135. Rpt. in Bloody Mary in the Mirror: Essays In Psychoanalytic Folkloristics. Jackson: University Press of Mississippi, 2002.

ELLIS, Bill, 2002, Making a Big Apple Crumble: The Role of Humor in Constructing a Global Response to Diasaster. New Directions in Folklore, June 6, NewFolk. http://www.temple.edu/isllc/ newfolk/bigapple/bigapple1.html, accessed August 16, 2008.

ELLIS, Bill, 2004, Lucifer Ascending: The Occult in Folklore and Popular Culture. Lexington: University Press of Kentucky.

EMERSON, Robert M., FRETZ, Rachel I. and SHAW, Linda L., 1995, Writing Ethnographic Fieldnotes. Chicago: University of Chicago Press.

FARRER, Claire R. (ed.), 1975, Women and Folklore: Images and Genres. Prospect Heights, IL:Waveland Press.

FINE, Gary Alan, 1992, Manufacturing Tales: Sex and Money in Contemporary Legends Knoxville: University of Tennessee Press.

FINE, Gary Alan and KHAWAJA, Irfan, 2005, 'Celebrating Arabs and Grateful Terrorists': Rumor and the Politics of Plausibility. Fine et al. 189-205.

Fine, Gary Alan and TURNER, Patricia A. 2001, Whispers on the Color Line: Rumor and Race in America. Berkeley: University of California Press.

Fine, Gary Alan, CAMPION-Vincent, Véronique and HEATH, Chip (eds), 2005, Rumor Mills: The Social Impact of Rumor and Legend. New Brunswick, NJ and London: Aldine Transaction.

Freidman, Diane P., ZAUHAR, Frances Murphy and Frey, Olivia (eds), 1993, The Intimate Critique: Autobiographical Literary Criticism. Durham, NC: Duke University Press.

GelfAND, Donald E., RASPA, Richard, BRILlER, Sherylyn H. and MYERS SCHIM, Stephanie (eds), 2005, End-of-Life Stories: Crossing Disciplinary Boundaries. Death and Suicide Series. NY: Springer.

GoLDSTEIN, Diane E., 2004, Once Upon a Virus: AIDS Legends and Vernacular Risk Perception. Logan, UT: Utah State University Press.

HAWES, Bess Lomax, 1968, La Llorona in Juvenile Hall. Western Folklore. 27:3: 153-170.

HolLIS, Susan Tower, PERSHING, Linda Pershing and YOUNG, M. Jane (eds), 1993, Feminist Theory and The Study of Folklore. Urbana: University of Illinois Press.

HufFORD, David J., 1995, 'Beings Without Bodies': An Experience-Centered Theory in the Belief in Spirits in Out of the Ordinary: Folklore and the Supernatural. Ed. Barbara Walker. Logan, UT: Utah State University Press: 11-45.

JORDAN, Rosan A., and KALCIK, Susan J. (eds), 1985, Women's Folklore, Women's Culture. Publications of the American Folklore Society. New Series. vol. 8. Philadelphia: University of Pennsylvania Press. 
KAPFERER, Jean-Noël, Rumors: Uses, Interpretations, and Images. New Brunswick, NJ: Transaction.

KLINTBERG, Bengt af., 1986, Rattan i pizzan, Stockholm, Norstedt.

KLINTBERG, Bengt af., 1994, Den Stulna Njuren. Stockholm, Norstedt.

KNOPF, Terry Ann, Rumor, Race and Riots. New Brunswick, NJ: Transaction (1996).

KoENIG, Frederick, 1985, Rumor in the Marketplace: The Social Psychology of Commercial Hearsay.

Dover, MA: Auburn House.

LANGLOIS, Janet L., 1978, 'Mary Whales, I Believe in You': Myth and Ritual Subdued. Indiana Folklore 1978. Rpt. in Indiana Folklore: A Reader. Ed. Linda Dégh. Bloomington: Indiana UP, 1980. 196-224.

LANGLOIS, Janet L., 1983a, Belle Gunness, the Lady Bluebeard: Symbolic Inversion in Verbal Art and American Culture. Signs: Journal of Women in Culture and Society 8.4 1983): 617-34.

LANGLoIS, Janet L., 1983b, The Belle Isle Bridge Incident: Legend Dialectic and Semiotic System in the 1943 Detroit Race Riots. Journal of American Folklore 96.380 (April-June 1983): 183-199.

LANGLOIS, Janet L., 1985a, Belle Gunness: the Lady Bluebeard. Bloomington: Indiana UP.

LANGLOIS, Janet L., 1985b, Belle Gunness, the Lady Bluebeard: Narrative Use of a Deviant Woman. Jordan and Kalcik, 109-124.

LANGLOIS, Janet L., 1991, 'Hold the Mayo': Purity and Danger in an AIDS Legend. Contemporary Legend 1.1: 153-172.

LANGLOIS, Janet L., 1993, Mothers' Double Talk, in Radner (ed.). Feminist Messages, 80-97.

LANGLOIS, Janet L., 2005-06, 'Other Worlds': The Return of the Dead and Other Mystical Experiences in Health-Related Contexts. International Society for Contemporary Legend Research Conference, Athens, GA, May 25-29, 2005 and American Folklore Society Annual Meeting, Milwaukee, Wisconsin, October 18-22, 2006.

LANGLOIS, Janet L., 2005, 'Celebrating Arabs': Tracing Legend and Rumor Labyrinths in Post-9/11 Detroit.” Tucker and Langlois: 219-236.

LAWLESS, Elaine, 1991, Women's Life Stories and Reciprocal Ethnography as Feminist and Emergent, Journal of Folklore Research 28:1: 35-60.

LAWLESS, Elaine, 2000, Reciprocal Ethnography: No One Said It was Going to be Easy. Journal of Folklore Research 37: 2/3: 197-205.

MiKKELSON, Barbara, Urban Legend Reference Pages. http://www.snopes.com, accessed August 16, 2008.

MiLLS, Margaret, 1993, Feminist Theory and the Study of Folklore: A Twenty-Year Trajectory Toward Theory. Western Folklore 52:2-4: 173-192.

MORIN, Edgar, 1971, Rumor in Orleans. Trans. NY: Pantheon.

ORING, Elliott (ed.), 1986, Folk Groups and Folklore Genres: An Introduction.Logan, UT: Utah State University Press (including Oring, “Folk Narratives": 121-145).

ORING, Elliott, 2008, Legendry and the Rhetoric of Truth. Journal of American Folklore. 121: 480 (Spring 2008): 127-166.

RADNER, Joan Newlon (ed.), 1993, Feminist Messages: Coding in Women's Folk Culture.

Urbana:University of Illinois Press. 
RENARD, Jean-Bruno, 1999, Rumeurs et légendes urbaines, Paris, Presses Universitaires de France, coll. «Que Sais-Je?»

SMITH, Paul, 1990, AIDS - Don't Die of Ignorance: Exploring the Cultural Complex of a Pandemic. A Nest of Vipers: Perspectives on Contemporary Legend. vol. 5. Ed. Gillian Bennett and Paul Smith. Sheffield, England: Sheffield Academic Press: 113-141.

SONTAG, Susan, 1988, AIDS and Its Metaphors. NY: Farrar, Straus and Giroux.

TANGHERLINI, Timothy R., 1998, 'Who Ya Gonna Call?': Ministers and the Mediation of Ghostly Threat in Danish Legend Tradition. Western Folklore 57: 2/3: 153-178.

TUCKER, Elizabeth, 2005, Campus Legends: A Handbook. Greenwood Folklore Handbooks. Westport, CT and London: Greenwood Press.

TUCKER, Elizabeth, 2005, Ghosts in Mirrors: Reflections of the Self. Tucker and Langlois. 186-203.

TUCKER, Elizabeth and LANGLOIS, Janet L., 2005, Introduction. Tucker and Langlois: 129-140.

TUCKER, Elizabeth and LANGLOIS, Janet L. (eds), 2005, Emerging Legends in Contemporary Society. Spec. Issue of Journal of American Folklore 118: 468.

TURNER, Patricia A., 2001, I Heard It through the Grapevine: Rumor in Afro-American Culture. Los Angeles: University of California Press.

ZeItLin, Steve J. and HarLow, Ilana (eds), 2001, Giving a Voice to Sorrow: Personal Responses to Death and Mourning. New York: Berkeley.

\section{RÉSUMÉS}

L'auteur décrit le terrain d'une «chasseur de légendes » aux États-Unis depuis les années 1970. Elle démontre ses différentes pratiques, en commençant par une ethnographie classique, puis une ethnographie intime, en passant par une ethnographie de l'ombre, pour aboutir à une forme d'ethnographie partagée.

This article examines the mutable relationships between fieldwork and oral literature through the personal journey of one American folklorist as she conducts field research on legendry over a 30-year period. Her first fieldwork experience in the 1970s draws on classic ethnographic and structural models to find meaning in young women's rituals and supernatural narratives. Her field research in the 1980's and 1990's pits feminist analysis against psychoanalytic approaches in "intimate ethnographies" exploring legendary narratives by and about women. Her analyses of other ethnographers' fieldwork in the 1990's and 2000's as a "shadow ethnographer" recognize rumors and legends as spaces of cultural dissonance, whether gender, class or race inflected. The article concludes with a comparative look at two extended field research projects in which a sense of "shared ethnography" emerges: collaborative work in community narrative on a woman serial killer, and in medical narrative about mystical experiences in health-related contexts, especially in end-of-life situations. 
INDEX

Thèmes : anthropologie (Amérique)

Index géographique : États-Unis

Keywords : Women, Legends, Structuralism, Feminism, Anthropology, United States

Mots-clés : femmes, structuralisme, légendes, feminisme 